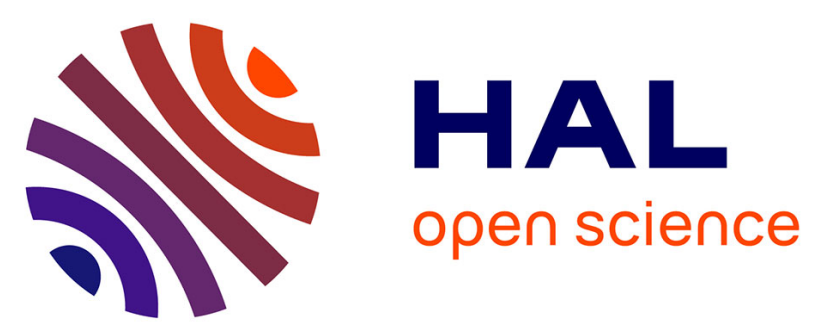

\title{
GROWTH OF $\beta$ BaB2O4 SINGLE GRYSTALS AND SHG EFFICIENCY MEASUREMENTS
}

B. Ferrand, Isabelle Chartier, C. Coatantiec, M. Couchaud, G. Rolland, Ch. Wyon, J. Aubert, D. Doizi

\section{> To cite this version:}

B. Ferrand, Isabelle Chartier, C. Coatantiec, M. Couchaud, G. Rolland, et al.. GROWTH OF $\beta$ BaB2O4 SINGLE GRYSTALS AND SHG EFFICIENCY MEASUREMENTS. Journal de Physique IV Proceedings, 1991, 01 (C7), pp.C7-753-C7-756. 10.1051/jp4:19917202 . jpa-00250883

\section{HAL Id: jpa-00250883 https://hal.science/jpa-00250883}

Submitted on 1 Jan 1991

HAL is a multi-disciplinary open access archive for the deposit and dissemination of scientific research documents, whether they are published or not. The documents may come from teaching and research institutions in France or abroad, or from public or private research centers.
L'archive ouverte pluridisciplinaire HAL, est destinée au dépôt et à la diffusion de documents scientifiques de niveau recherche, publiés ou non, émanant des établissements d'enseignement et de recherche français ou étrangers, des laboratoires publics ou privés. 


\title{
GROWTH OF $\beta \mathrm{BaB}_{2} \mathrm{O}_{4}$ SINGLE GRYSTALS AND SHG EFFICIENCY MEASUREMENTS
}

\author{
B. FER RAND, I. CHARTIER, C. COATANTIEC, M. COUCHAUD, G. ROLLAND, \\ Ch. WYON, J.J. AUBERT and D. DOIZI*
}

CEA, DTA/LETI/D.OPT, CENG, $85 X, F$-38041 Grenoble cedex, France

'DPE-SOL, CEN-SACLAY, F-91191 Gif sur Yvette cedex, France

\begin{abstract}
We report here the growth and characterization of non linear single crystals $\beta \mathrm{BaB}_{2} \mathrm{O}_{1}(\mathrm{BBO})$ which is an interesting material for second harmonic generation. Single crystals were grown from $\mathrm{Na}_{2} \mathrm{O}-\mathrm{B}_{2} \mathrm{O}_{3}$ solutions using the top seeded solution growth method. The experimental set up included a Nd:YAG, $Q$ switched, focalised with a cylindrical lens on the samples. Efficiency up to $40 \%$ were obtained using $6 \mathrm{~mm}$ long crystal.
\end{abstract}

\section{1. - Introduction}

$\beta \mathrm{BaB}_{2} \mathrm{O}_{4}(\mathrm{BBO})$ is an interesting material for second harmonic generation (SHG) (1). It exhibits high damage threshold and a wide transparency range (2). $\mathrm{BaB}_{2} \mathrm{O}_{4}$ is known to exist in two phases : a high temperature $\alpha$ phase and a low temperature $\beta$ phase with a transition temperature of about $925^{\circ} \mathrm{C} \mathrm{(3).} \alpha \mathrm{BaB}_{2} \mathrm{O}_{4}$ melts congruently at $1096^{\circ} \mathrm{C}$ but the growth of $\beta$ phase requires a growth temperature below $925^{\circ} \mathrm{C}$ in a solvent. The real success in growing $\beta \mathrm{BaB}_{2} \mathrm{O}_{4}$ came with discovery of a suitable solvent. The workers of Fujian Institute have studied all of the pratical solvent for this material : $\mathrm{BaCl}_{2}, \mathrm{BaF}_{2}, \mathrm{Li}_{2} \mathrm{O}, \mathrm{NaBO}_{2}$ and $\mathrm{Na}_{2} \mathrm{O}$ (4). They reported that $\mathrm{Na}_{2} \mathrm{O}$ yields the best results in terms of crystal size and defect density.

\section{2. - Crystal growth procedure}

\section{1 - Preparation of charges}

Several meit compositions were investigated in the system $\mathrm{BBO}-\mathrm{Na}_{2} \mathrm{O}-\mathrm{B}_{2} \mathrm{O}_{3}$. In order to obtain the desired low temperature $\beta$ phase, growth must be carried out from solution below $925^{\circ} \mathrm{C}$. With $\mathrm{Na}_{2} \mathrm{O}-\mathrm{B}_{2} \mathrm{O}_{3}$ as solvent, we find that $\beta \mathrm{BaB}_{2} \mathrm{O}_{4}$ can be crystallized at about $900^{\circ} \mathrm{C}$ from solutions with typical composition of $80 \%$ mole $\mathrm{BBO}-16 \%$ mole $\mathrm{Na}_{2} \mathrm{O}-4 \%$ mole $\mathrm{B}_{2} \mathrm{O}_{3}$. Charges were weighed out and fractionnal amounts were placed in pure platinium crucible to be melted in a synthesis furnace at $1025^{\circ} \mathrm{C}$.

\section{2 - Top seeded solution growth apparatus}

High thermal gradient furnace was used in order to initiate a good growth from the seeds and to minimize the defects density in the crystals. At the melt surface the axial temperature gradient was about $50^{\circ} \mathrm{C} / \mathrm{cm}$. BBO seeds were held rigidly using a platinum holder. Before seeding the melt was heated at about $1000^{\circ} \mathrm{C}$ during several hours. 


\section{3 - Growth conditions}

Crystal growth experiments were performed with the use of seeds oriented along the $y$-axis. BBO seeds having a rotation rate of $10-25 \mathrm{rpm}$ were introduced carefully in the melt in order to avoid nucleation, at about $900^{\circ} \mathrm{C}$ to minimize solution viscosities. Typically we used a cooling rate of $0.025^{\circ} \mathrm{C} /$ hour and a pulling rate of $1 \mathrm{~mm} /$ day.

\section{3. - $\underline{\text { Results }}$}

BBO crystals boules of $40 \mathrm{~mm}$ in diameter and $10 \mathrm{~mm}$ in thickness were grown. The crystals had tendency to fracture along the basal plane during cooling. Most crystals grown presented internal defects, typically : solvent inclusions, fractures and cleavages.

\section{4. - Characterization}

After growth, crystals were characterized by optical microscopy in order to localise the defects. Following these observations, we prepared single parallelepipedic crystals $\left(5 \times 5 \times 8 \mathrm{~mm}^{3}\right)$ of good optical quality, to make the SHG efficiency measurements. Two plane and parallele faces were then oriented and polished. Two orientations were studied : one perpendicular to the optical axis and one at $22^{\circ} 8$ of this axis corresponding with the type I phase matching for SHG at $\lambda=1064 \mathrm{~nm}$.

The spectral transparency range was measured using a spectrophotometer and found to spread from $200 \mathrm{~nm}$ to $2500 \mathrm{~nm}$ (at a level of 1/2) (figure 1).

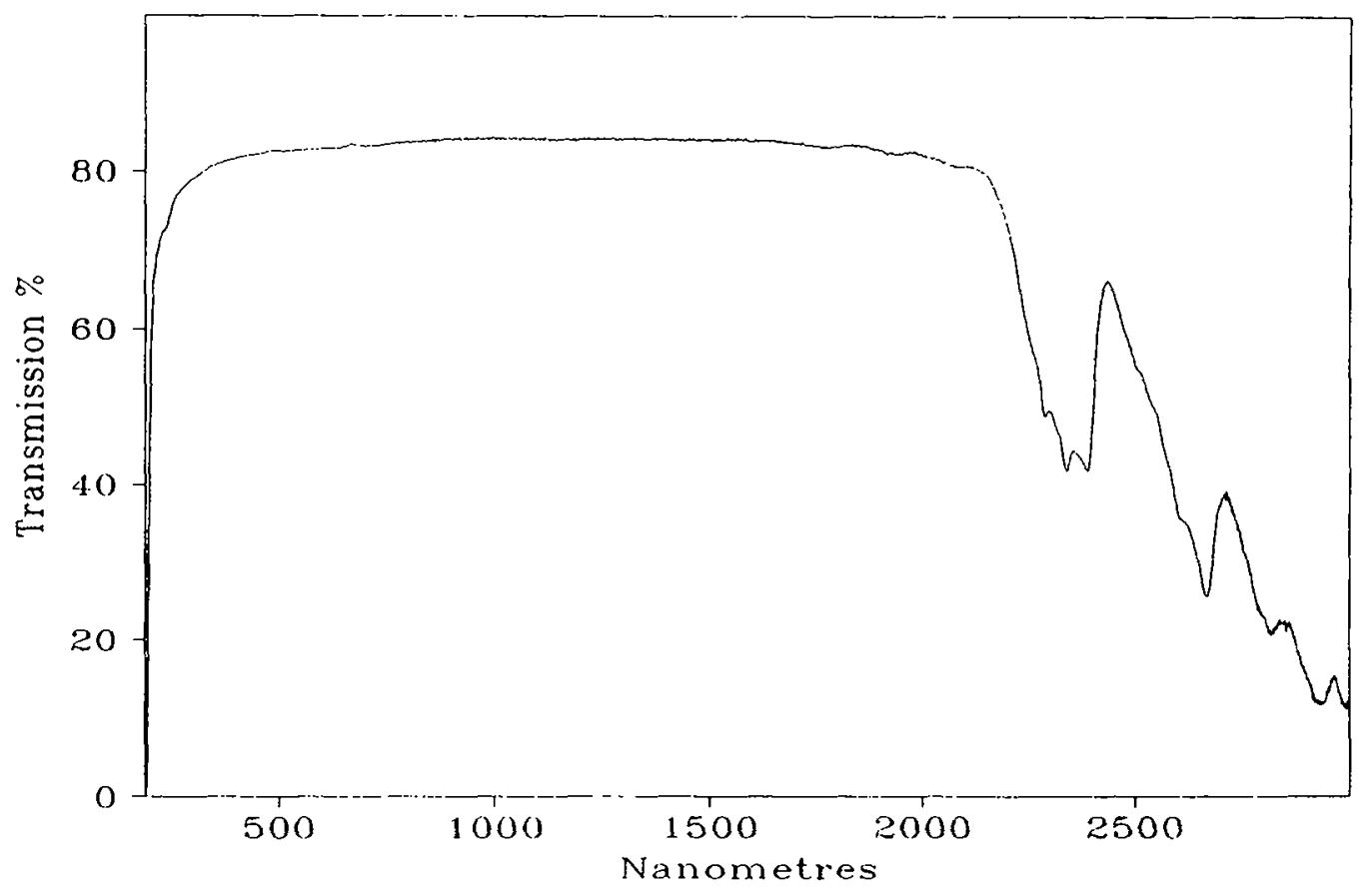

FIG. 1 - Transmission of $\beta \mathrm{BaB} 2 \mathrm{O} 4$ crystal 


\section{5. - Second harmonic generation experiments}

\section{1 - Crystal orientation}

The low temperature phase for baryum metaborate can be indexed with a monoclinique cell where $a=11.133 \AA, b=12.67 \AA, c=8.381 \AA$ and $\beta=100.03^{\circ}(5)$. In this representation, the phase matching direction for the sezond harmonic generation $\left(22^{\circ} 8\right.$ from the optical axis) is not perpendicular to a common crystallographic plane (6). So the problem consisted to determine this SHG plane. Thus, we found two crystallographic planes, (010) and (201), which are both perpendicular to the SHG plane. The orlentation was realized with the Laue method. Only one pattern was required, with the software "Orient Express" to locate accurately the crystallographic planes (7). When these two (010) and (201) orientations are located, we cut and polish, perpendicular to them, two parallele faces.

\section{2 - Results}

The SHG measurements were made using as the fondamental beam source a Q-Switched Nd:YAG having the following properties :

$-\lambda=1,064 \mu \mathrm{m}$

$-\nu=1 \mathrm{KHz}$

$-\tau=17 \mathrm{~ns}$

$-E_{\text {pules }}=50 \mathrm{~mJ}$ linearly polarized around $80 \%$ (so the usefull energy was $40 \mathrm{~mJ}$ )

- beam quality $=3$ times the diffraction limit

The beam was focused using a cylindrical lens and its size in the BBO crystal was (FWHM) : $290 \mathrm{x}$ $4 \mu \mathrm{m}^{2}$ leading to a power density (FWHM) of $0,27 \mathrm{GW} / \mathrm{cm}^{2}$. With this experimental set up and using a $6 \mathrm{~mm}$ long BBO crystal in the type I phase matching configuration, an energy of $17 \mathrm{~mJ}$ was generated at $\lambda=532 \mathrm{~nm}$ which gives a conversion efficiency of $\mathbf{4 0} \%$.

\section{6. - Conclusion}

Single crystals of $\beta \quad \mathrm{BaB}_{2} \mathrm{O}_{4}$ have been grown from $\mathrm{Na}_{2} \mathrm{O}-\mathrm{B}_{2} \mathrm{O}_{3}$ solutions. High thermal gradient furnace was used. Crystals grown from " $y^{\prime \prime}$ oriented seed had tendency to fracture along the basal plane and to contain some optical defects. Parallelepipedic samples (5 $55 \times 8 \mathrm{~mm}$ ) have been prepared and tested for second harmonic generation efficiency. Values up to $40 \%$ were obtained. Crystal growth with " $z$ " oriented seeds are presently in progress. 


\section{7. - Acknowledgements}

The authors are indebted to all the people of the dielectric material and laser groupe of D.OPT for their contribution in the growth and characterization of the BBO crystals. They would like also to thank J.P VASSALI and B. FRANCOIS for the preparation of samples and F. LAUGIER for RX orientation.

\section{8. - References}

(1) - Q. HUANG, J. LIANG

Acta Phys. Sinica $\underline{30} 5591981$

(2) C.T CHEN, B. WU, G. YOU, Y. HUANG

Digest Tech. Papers XIII IQEC Paper MCC5 (1984)

(3) E.M LEVIN, H.F.Mc MURDIE

J. Res. Natl. Bur. Std US 42131 (1949)

(4) A.D JIANG, F. CHENG, Q. LIN, Z.S CHENG, Y. ZHENG

J. Cryst. Growth $\underline{79} 963$ (1986)

(5) K.H HUBNER

Neues Jahrb. Min. Mon. $\underline{335}$ (1969)

(6) K.KATO

IEEE J. Quantum Electron. QE 221013 (1986)

(7) "Orient Express"

Software Copyright ILL-CEA distributed by CYBERSTAR SA 